\title{
Ülkemizde Alternatif Yağ Bitkilerinin Durumu
}

\author{
Abdurrahim Yilmaz ${ }^{1 *}$, Hilal Yılmaz ${ }^{2}$, Yusuf Arslan ${ }^{3}$, Vahdettin Çiftçi ${ }^{4}$, Faheem Shahzad Baloch $^{5}$ \\ 1* Bolu Abant İzzet Baysal Üniversitesi, Ziraat Fakültesi, Tarla Bitkileri Bölümü, Bolu, Türkiye, (*ORCID: 0000-0001-9991-1792; ), ayilmaz88@ hotmail.com \\ ${ }^{2}$ Kocaeli Üniversitesi, İzmit MYO, Bitkisel ve Hayvansal Üretim Programı, Kocaeli, Türkiye (ORCID: 0000-0001-9138-3382), hilal.yilmaz@kocaeli.edu.tr \\ ${ }^{3}$ Bolu Abant İzzet Baysal Üniversitesi, Ziraat Fakültesi, Tarla Bitkileri Bölümü, Bolu, Türkiye (ORCID: 0000-0001-8496-6037), yarslantarm@gmail.com \\ ${ }^{4}$ Bolu Abant İzzet Baysal Üniversitesi, Ziraat Fakültesi, Tarla Bitkileri Bölümü, Bolu, Türkiye (ORCID: 0000-0002-0440-5959), vahdet2565@ yahoo.com \\ ${ }^{5}$ Sivas Bilim ve Teknoloji Üniversitesi, Tarım Bilimleri ve Teknoloji Fakültesi, Sivas, Türkiye (ORCID: 0000-0002-7470-0080), balochfaheem13@ gmail.com
}

(İlk Geliş Tarihi Aralık 2020 ve Kabul Tarihi Ocak 2021)

(DOI: $10.31590 /$ ejosat.843220)

ATIF/REFERENCE: Yılmaz, A., Yılmaz, H., Arslan, Y., Çiftçi, V. \& Baloch, F. S. (2021). Ülkemizde Alternatif Yağ Bitkilerinin Durumu. Avrupa Bilim ve Teknoloji Dergisi, (22), 93-100.

\section{$\ddot{O} \mathbf{z}$}

Yağlı tohumlu bitkiler, içerdikleri primer ve sekonder metabolitler (yağ, protein, karbonhidrat, vitamin, mineral, fenolik ve antioksidan) bakımından zengin olan, insan ve hayvan beslenmesinin yanı sıra sanayi sektörü için de çok yönlü kullanım olanağına sahip olan önemli hammadde kaynaklarıdır. Ülkemizde yağlı tohumlu bitkiler arasında ekim alanı, üretim ve yağ tüketimi bakımından ilk sırayı ayçiçeği bitkisi almaktadır. Ayçiçeği bitkisinden sonra pamuk, soya, yer fıstığı, kolza ve aspir gibi bitkiler bu parametrelerde ön sırada yer alan yağ bitkilerindendir. Ancak nüfusun artmasıyla birlikte yağ tüketimi de artmakta, ülkemizde üretilen bitkisel yağ miktarı talebi karşılayamamakta ve bu nedenle yağ açı̆̆ı oluşmaktadır. Gereksinim duyulan yağ ihtiyacının karşılanması için her yıl bitkisel yağ ithal edilmekte ve döviz kaybına uğranmaktadır. Ülkemizde kişi başına düşen bitkisel yağ tüketiminin gelişmiş ülkelere göre düşük olması da ayrıca dikkat edilmesi gereken hususlardandır. Yağ açığının giderilmesi adına alternatif yağ bitkilerinin araştırılması ve yaygınlaştırılması gerekmektedir. Bu derlemede alternatif yağ bitkileri potansiyeline sahip olan aspir, kolza, susam, ketencik, pelemir, crambe ve keten bitkilerinin dünya ve ülkemiz açısından önemi hakkında bilgiler verilmiştir.

Anahtar Kelimeler: Alternatif Yağ Bitkileri, Aspir, Kolza, Susam, Ketencik

\section{Status of Alternative Oilseed Crops in our Country}

\begin{abstract}
Oilseed crops rich in primary and secondary metabolites (fat, protein, carbohydrates, vitamins, minerals, phenolics, and antioxidants) constitute an essential source of raw material for human and animal nutrition well as for the industrial sector. The sunflower plant takes the first place in terms of harvested area, production, and oil consumption among the oilseed crops in our country. After the sunflower plant, plants such as cotton, soybean, peanut, rapeseed, and safflower are among the oilseed crops at the forefront of these parameters. With the increase of population and plant oil consumption, the amount of plant oil produced in our country can not satisfy the demand, and plant oil deficits occur. To meet the required oil demand, plant oil is imported every year, and foreign currency is lost. The fact that vegetable oil consumption per capita in our country is low compared to developed countries is also among the matters to be considered. To eliminate the vegetable oil deficit, alternative oilseed crops should be researched and expanded. In this review, information about the importance to the world and our country of safflower, rapeseed, sesame, camelina, cephalaria, crambe, and flax plants which have the potential of alternative oilseed crops is given.
\end{abstract}

Keywords: Alternative Oilseed Crops, Safflower, Rapeseed, Sesame, Camelina

*Sorumlu Yazar: ayilmaz88@ hotmail.com 


\section{Giriş}

Hayvansal kökenli yağların maliyeti pahalı ve üretimi yeterli değildir. $\mathrm{Bu}$ nedenle insan beslenmesi için gereksinim duyulan yağların büyük bir kısmı, bitkisel kökenli yağlardan karşılanmaktadır (Kolsarıcı ve ark., 2015). Yağlı tohumlu bitkiler içerdikleri yağ, protein, karbonhidrat, mineral maddeler ve vitaminler sayesinde insan ve hayvan beslenmesinde önemli bir yere sahiptir. 1 gram yağın vücuda sağladığı enerjinin $9 \mathrm{kcal}$. olduğu, aynı miktar proteinin 4 kcal. ve karbonhidratın $4.5 \mathrm{kcal}$. enerji verdiği belirtilmektedir (Bahar, 1999). Sağlıklı yetişkin bir insanın günlük aktivitesi için 2500-3000 kaloriye gereksinimi olduğu ve bu kalorinin \%30-35'inin yağlardan karşılanması gerektiği tavsiye edilmektedir. $\mathrm{Bu}$ durumda kişi başına yılda yaklaşık $23 \mathrm{~kg}$ yağ tüketilmesi gerekmektedir. Ülkemizde ise yılda kişi başı yaklaşık $21 \mathrm{~kg}$ yağ tüketilmektedir. Gelişmiş ülkelerde sağlıklı bir beslenme için kişi başı asgari yağ miktarının $24 \mathrm{~kg}$ olması gerektiği bildirilmektedir. Bu değer dikkate alındığında ülkemizde yağ tüketimi bakımından sağlıklı beslenmenin yeterli düzeyde olmadığı söylenebilir (Kolsarıcı ve ark., 2015).

Ülkemiz iklim ve toprak özellikleri dikkate alındığında, yağlı tohumlu bitkilerin üretimi için büyük bir potansiyele sahiptir. Yağlı tohumlu bitkiler arasında ekim alanı, üretim ve yağ tüketimi bakımından ortalama \%70'lik pay ile ilk sırayı ayçiçeği bitkisi almaktadır (Taşkaya ve Uçurum, 2012). Ancak nüfusun artmasıyla birlikte yağ tüketimi artmakta, ülkemizde üretilen bitkisel yağ miktarı oluşan talebi karşılayamamakta ve bu nedenle yağ açığı oluşmaktadır.

2019/20 sezonu USDA raporu verilerine göre; dünyada toplam yağlı tohum üretimi yaklaşık 577,15 milyon metrik tondur. Soya fasulyesi 337,14 milyon metrik tonluk üretimi ile birinci sırada, kolza (kanola) 68.20 milyon metrik tonluk üretim değeri ile ikinci sıradadır. Ayçiçeği ise 55,04 milyon metrik tonluk üretim değeri ile üçüncü sırada yer almaktadır. Bu değerleri 46,11 milyon metrik ton ile yer fistığ 1 , 44,95 milyon metrik ton ile pamuk tohumu ve 19.85 milyon metrik tonluk üretim ile de palm çekirdeği izlemektedir. Dünya ticaretinde önemli bir yeri olan yağlı tohumların toplam ithalat/ihracat miktarı 180,73 milyon metrik tondur. Yaklaşık 160 milyon metrik ton ile dünya yağlı tohumlar ticaretinde ilk sırayı soya fasulyesi, ikinci sırayı 15 milyon metrik ton ile kanola, bunları da sırayla 4 milyon metrik ton ile yer fistığı, 3 milyon metrik ton ile ayçiçeği ve 0,7 milyon metrik ton ile pamuk tohumu takip etmektedir (USDA, 2020).

Türkiye'de 2019 yılı yağlı tohumlar üretiminde birinci sırada yer alan ayçiçeği üretimi yaklaşık 1,9 milyon ton, pamuk (çiğit) üretimi 1,320 milyon ton, kolza üretimi 180 bin ton, soya üretimi 150 bin ton, aspir üretimi 21,9 bin ton ve susam üretimi 16,9 bin tondur. En çok ekim alanına 675,9 bin ha ile ayçiçeği, daha sonra sirasiyla 477,9 bin ha ile pamuk, 52,5 bin ha ile kolza, 35,3 bin ha ile soya, 24,9 bin ha ile susam ve 15,9 bin ha ile aspir bitkisi sahiptir. Bu verilere göre ülkemizde 2019 yılında yaklaşık olarak 1,28 milyon ha alanda 3,6 ton yağlı tohumlu bitki üretilmiştir. Ayçiçeğinin yurt içi toplam kullanım değeri 4,7 milyon ton olup, 2,8 milyon tonu ithalat ile sağlanmaktadır. Soya bitkisinin yurt içi tüketim değeri 2,6 milyon ton olup, bunun 2,4 milyon tonluk gibi büyük bir bölümü ise ithalat ile temin edilmektedir (TÜİK, 2020).

Ekolojik olarak çok farklı iklim ve toprak özelliklerine sahip olan ülkemizde yağlı tohumlu bitki yetiştiriciliğinde yoğun olarak ayçiçeği tarımı yapılmaktadır. Yapılan üretim, tüketim miktarımızı karşılayamamaktadır. Hem yağ açığını kapatmak hem de gelecekte dış pazarlarda yer alabilmek için mutlaka ürün çeşitliliğinin ve üretimin artırılması gerekmektedir.

Tarım bakanlığı tarafından yağlı tohum tarımını teşvik edici sistemler uygulanarak alternatif yağ bitkilerinin yetiştiriciliğinin yaygınlaştırılması, yöreye uygun ürün deseni oluşturularak alternatif yă̆ bitkilerinin ekim nöbetine girmesi, nadas alanlarının bu bitkiler ile değerlendirilmesi, araştırma projelerinin desteklenmesi ile planlı ve programlı bir çalışma yapılarak tohumluk ihtiyacının karşılanması; bitkisel yă üretiminde kendine yetebilecek ve üretim fazlasını ihraç edebilecek düzeye gelebilen bir ülke olmanın önünü açabilecektir (Kolsarıcı ve ark., 2005). Bunun yanı sıra ıslah programlarıyla alternatif yăg bitkileri tarımında karşılaşılan sorunların yeni çeşitler geliştirilerek giderilmesi, var olan çeşitlerinin çiftçiye tanıtılarak kullanılması sağlanmalıdır. Ülkemizde yetiştiriciliği yapılan alternatif yă̆ bitkileri; Kolza (kanola), Aspir, Ketencik, Susam ve Pelemir'dir. Bu bitkilerin tescilli çeşit sayıları yoğun olarak tarımı yapılan ayçiçeği ve nispeten tarımı yapılan soya, kolza ve susam bitkileri ile karşılaştırıldığında oldukça yetersiz kalmaktadır (Şekil 1).

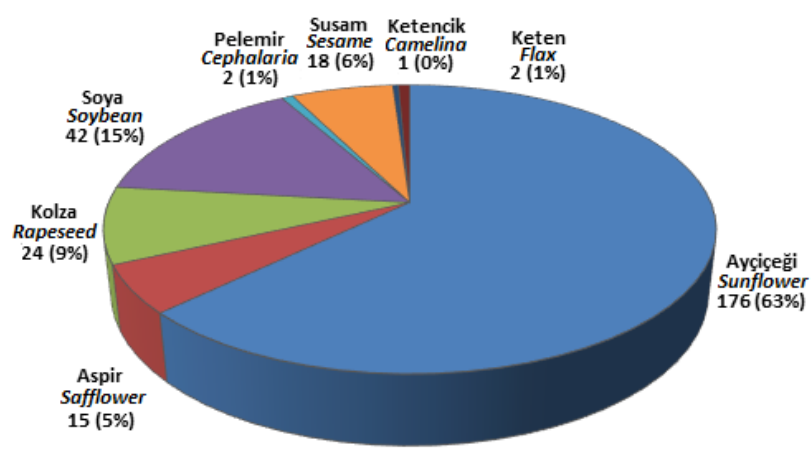

Şekil 1. Türkiye'de yağ bitkileri tescilli çeşit sayısı

Ülkemizde tarımı yapılan bazı yağ bitkilerinin devlet (T.C. Tarım ve Orman Bakanlığı) tarafindan desteklemeleri sağlanmaktadır (Çizelge 1). Ayçiçeği, pamuk, soya, kanola ve aspir bitkisine yapılan desteklerin yanı sira susam, keten, ketencik, pelemir ve crambe gibi diğer alternatif yağ bitkilerine de gerekli desteklemelerin yapılması beklenmektedir.

Tablo 1. Yağlı Tohum Destekleme (tl/ton)

\begin{tabular}{l|cccccccc} 
Bitki-Yıl & $\mathbf{2 0 1 3}$ & $\mathbf{2 0 1 4}$ & $\mathbf{2 0 1 5}$ & $\mathbf{2 0 1 6}$ & $\mathbf{2 0 1 7}$ & $\mathbf{2 0 1 8}$ & $\mathbf{2 0 1 9}$ & $\mathbf{2 0 2 0}$ \\
\hline Ayçiçeği & 240 & 300 & 300 & 400 & 400 & 400 & 400 & 400 \\
Pamuk & 500 & 550 & 650 & 750 & 800 & 800 & 800 & 800 \\
Soya & 500 & 500 & 500 & 600 & 600 & 600 & 600 & 600 \\
Kanola & 400 & 400 & 400 & 500 & 500 & 500 & 500 & 500 \\
Aspir & 450 & 450 & 450 & 550 & 550 & 550 & 550 & 550
\end{tabular}

Ülkemizde geleneksel yağ bitkilerinden ayçiçeği ve soya fasulyesi yetiştiriciliğinde en önemli etken sulamadır. Sulama suyu yağışın yeterli düzeyde olduğu bölgelerde daha ekonomik olarak sağlanabildiğinden bu bölgelerde bu bitkilerin tarımı daha çok yapılabilmektedir. Ülkemizde bu özelliğe sahip üretim alanları az olduğundan ve bitkilerdeki verim artışı ile mevcut yağ açığını kapatmak mümkün olmadığından alternatif yağ bitkilerinin yaygınlaştırılması gerekmektedir. 


\section{Alternatif Yăg Bitkileri}

\subsection{Aspir (Carthamus tinctorius L.)}

Aspir tohumlarından elde edilen yağ, insan beslenmesinde çok önemli olan yüksek oranda $\mathrm{E}$ vitamini ve doymamış yă̆ asitleri (\%78 linoleik asit) içermektedir (Arslan ve ark., 1999; Öztürk ve ark., 2007). Aspir bitkisi yemeklik yağ üretimi haricinde sabun, boya, vernik ve cila yapımından yemeklerde tatlandırıcı ve renklendirici olarak çok farklı alanlarda (biodizel, boya maddesi, hayvan küspesi vs) değerlendirilen, kullanım alanları oldukça geniş olan önemli bir ticari bitkidir (Corleto ve ark., 1997; Zhang ve ark., 1997; Esendal, 1988; Esendal, 2001). Aspir, kuraklığa dayanıklı ve yağmur sularını verimli kullanan, ayrıca içerdiği yağ oranı ve yağ kalitesi ile üretim desenimiz içerisinde yer alması gereken önemli bir alternatif yağ bitkisidir (Bayramin, 2006).

Aspir, adaptasyon sınırlarının geniş olması nedeniyle farklı ekolojilerde yetişebilen, derine inen kök aksamı ile kurağa ve sıcağa toleransı yüksek, özellikle kuru tarım yapılan alanlarda ekim nöbetinde yer alması gereken önemli bir yă bitkisidir (Dajue ve Mundel, 1996; Machado, 2004). 2020 TÜIK verilerine göre ülkemizde aspir bitkisinin ortalama verimi dünya ortalamasının (90 kg/da) üzerinde olup 141,7 kg/da'dır. Ekim alanına göre aspir yetiştiriciliği yapan ilk beş şehir sırasıyla Ankara, Aksaray, Muş, Konya ve Nevşehir'dir. Ülkemizde aspir bitkisi ekim alanlarının yıllara göre dağılımı verilen teşvik ve desteklemelere rağmen düzenli bir yükseliş grafiği yakalayamamıştır (Şekil 2).

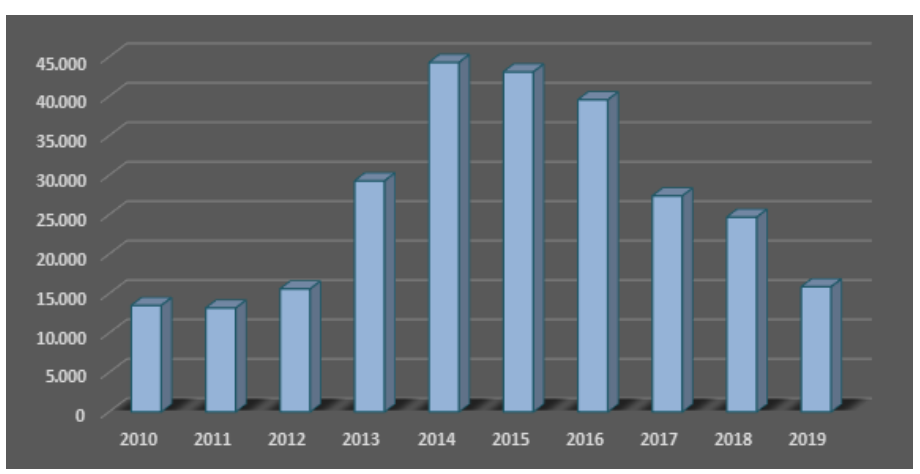

Şekil 2. Türkiye'de Aspir Bitkisi Ekim Alanlarının Yıllara Göre Dağılımı (ha)

Aspir bitkisi, iklim isteklerinin geniş olması, yazlık/kışlık formlarının bulunması ve buğday tarımında kullanılan mekanizasyona uygunluğu ile ülkemizde geniş alanlarda ekilebilecek potansiyel bir yağ bitkisidir (Uysal ve ark., 2006). Tahıllar ile ekim nöbetine katılması, hem hastalık ve zararlıların azaltılması hem de kök derinliği sayesinde nemden yararlanılmasını sağlamaktadır. Ayçiçeği işleyen fabrikada cihazlarda hiçbir değişiklik yapılmadan aspir bitkisi işlenebilmektedir. Yağ açığının kapatılmasında aspir bitkisinin ürün desenine koyulması oldukça önemlidir (Coşkun, 2014). Dünya'da önemi hızla artmasına rağmen ülkemizde yeterince tanınmadığı ve önemi yeterince kavranmadığı için bugüne kadar tarımında önemli bir gelişme yaşanamamıştır (Uysal ve ark., 2006).

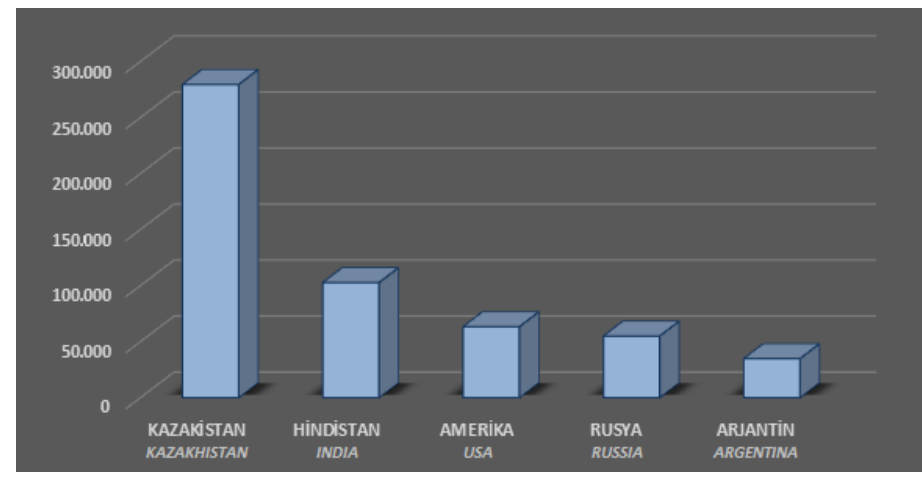

Şekil 3. Dünya'da En Yüksek Aspir Ekim Alanına sahip ilk 5 ülke 2018 (ha)

2018 y1lı dünya aspir ekim alanı 694,8 bin hektardır. Kazakistan tek başına tüm aspir ekim alanının \%40,3'üne sahip iken, toplam aspir tohumu üretiminin \%34,2'sini karşılamaktadır. Amerika ise aspir ekim alanlarının \%9,1'ini ve toplam aspir tohumu üretiminin \%17'sini karşılamaktadır (Şekil 3). Ülkemiz şartlarına uyum sağlayabilen yüksek verimli yağlı tohumu olan aspir bitkisinin üretimi teşvik edilmeli ve ekim alanları hızlı bir şekilde artırılmalıdır.

\subsection{Kolza/Kanola (Brassica napus L.)}

Dünya yağ üretiminde soya bitkisinden sonra en fazla tarımı yapılan bitki kolzadır. Yağında bulunan yüksek erusik asit ve glukosinolat, insan ve hayvan sağlığına zararlı olmasından dolayı bitki 1slahçıları tarafından geliştirilerek erusik asit (\%2'den az) ve glukosinolat ( $30 \mu \mathrm{mol} /$ gramın altında) düşük olan 'Kanola' ismi ile adlandırılan çeşitler geliştirilmiştir (Raymer, 2002). Kolza tohumları \%40-45 yağ ve kolza küspesi \%37 protein içermektedir. Yağının oleik asitçe zengin olması, omega3 ve omega-6 içermesi, E vitamini içeriğinin yüksek olması, kaynama noktasının yüksek oluşu $\left(238^{\circ} \mathrm{C}\right)$, küspesinin soya küspesine çok yakın protein (\%37) içermesi, kolza bitkisini dünyada en fazla tarımı yapılan 2. yağlı tohum bitkisi konumuna getiren nedenlerdendir. Bu nedenlerden dolayı kolza bitkisinin en iyi yağ bitkilerinden olduğu söylenebilir (Bayramin, 2006; Gizlenci ve ark., 2007). Dünyada kolza bitkisi, yemeklik yağ olarak kullanımının haricinde fosil yakıtların azalmas1, petrol fiyatlarındaki dalgalanmalar ve ekonomik krizler nedeniyle petrole alternatif araç yakıtı olarak (Biyodizel) kullanılabilmektedir. $\mathrm{Bu}$ vesile ile gelecekte kolza bitkisinin daha önemli bir stratejik konuma sahip olacağı tahmin edilmektedir (Gizlenci ve ark., 2007). Dünya'da şu an itibariyle biyodizel üretiminin \%86'sı kolza bitkisinden sağlanmaktadır (Gizlenci ve ark., 2012). Türkiye'de kolza, buğdayın yetiştirilebildiği alanlarda gerekli teknikler uygulandığında rahatlıkla üretilebilmektedir. Ancak TÜİK 2019 verileri incelendiğinde kolza tarımı ülkemizde istenen düzeylere ulaşamamıştır. Ülkemizde son on yıl içerisinde kolza bitkisi ekim alanlarının inişli-çıkışlı bir seyir izlediği dikkati çekmekle birlikte son yıllardaki artış eğilimi de bu bitkinin ülkemizdeki üretiminin giderek artacağına dair beklentileri karşılamaktadır (Şekil 4). 


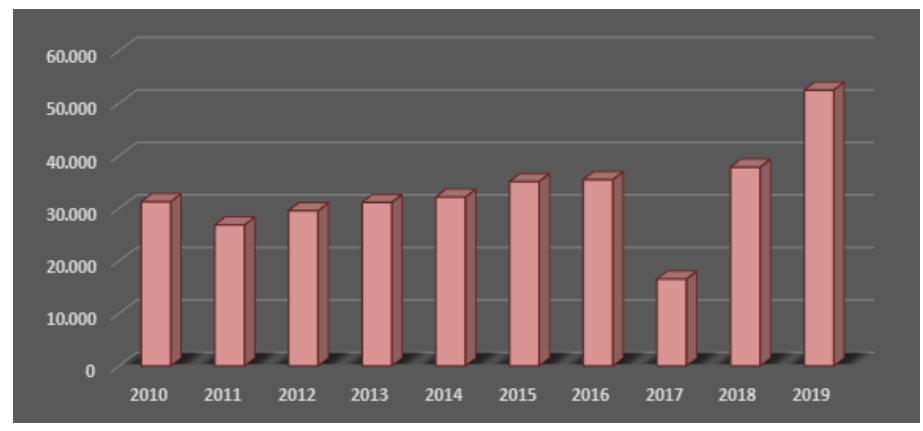

Şekil 4. Türkiye'de Kolza Bitkisi Ekim Alanlarının Yıllara Göre Dağılımı (ha)

Dünya kolza verim ortalaması $200 \mathrm{~kg} \mathrm{da}^{-1}$ 'dır. TÜİK 2020 verileri incelendiğinde ise ülkemizde kolza bitkisinin ortalama veriminin $343 \mathrm{~kg} / \mathrm{da}$ olduğu görülmektedir. Ortalama verim bölgelere ve yetiştirme tekniğine göre değişmekte olup Ankara'da 400 kg/da olan kolza verimi Çorum'da $188 \mathrm{~kg} / \mathrm{da}$ olarak kaydedilmiştir (TÜİK, 2020). İllerin verim değerlerindeki bu farklılık, bölge ekolojisine göre uygun kolza çeşidi seçiminin önemli olduğunu ve üretimi yapılacak çeşit seçiminin de bölgedeki verim denemeleri sonuçlarına göre yapılması gerektiğini göstermektedir (Arslan ve ark., 2007). Ekim alanlarında ise yetiştiriciliği yapan ilk beş şehir sırasıyla; Tekirdağ, Konya, İstanbul, Edirne ve Kirklareli'dir. Dünya kolza ekim alanları incelendiğinde 2018 yılında en fazla ekim alanları 9,12 milyon ha ile Kanada, 6,7 milyon ha ile Hindistan, 6,6 milyon ha ile Çin, 3,2 milyon ha ile Avustralya ve 1,6 milyon ha ile Fransa'dır (Şekil 5). Ülkemizde ise kolza tarımına ayrılan alan 2017 y1lında 16,5 bin hektara gerilerken 2019 y1lında 52,5 bin ha alanda ekimi yapılmıştır. Dünya ülkeleri ile kıyaslandığında ve yetiştiricilik için elverişli potansiyelimiz değerlendirildiğinde ülkemizdeki üretim durumunun oldukça yetersiz kaldığı görülmektedir.

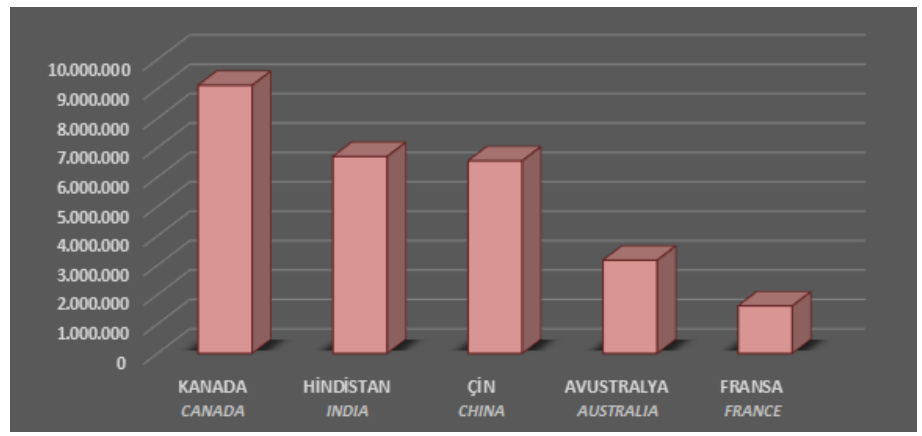

Şekil 5. Dünya'da En Yüksek Kolza Ekim Alanına sahip ilk 5 ülke (ha)

2019/2020 USDA raporuna göre dünya yağlı tohum üretiminin yaklaşık \%12'si kolza bitkisinden karşılanmaktadır. Ülkemizde ise yağlı tohum üretiminin $\% 5$ 'i kolza tarımından karşılanmaktadır. Yüksek verimli ve daha fazla üretim potansiyeli olan bu bitkinin de üretimi teşvik edilmeli ve ülkemizdeki ekim alanları hızlı bir şekilde arttırılmalıdır.

\subsection{Susam (Sesamum indicum L.)}

Dünya'da kültüre alınan ilk yağlı tohum bitkisi olan ve 5000 yılı aşkın süredir insanoğlu tarafından kullanılan, köklü bir geçmişe ve zengin bir kullanım alanına sahip olan bu bitki Türk kültüründe tahin, tahin helvası ve simit gibi çok sevilen besinlerde kullanılan önemli bir yă̆ bitkisidir. Susam tohumlarında \%50-60 oranında yağ bulunmakta ve bu yağın yaklaşık \%35-45'ini değişen oranda linoleik ve olaeik asitler oluşturmaktadır (Liu ve ark., 1992; Baydar, 2005). Yağda çözünebilen en güçlü doğal antioksidanlar olan tokoferollerce (294-528 mg/kg) zengindir (Yoshida ve Takagi, 1997). Ayrıca sesamolin $(\% 0,3-0,5)$ ve sesamin $(\% 0,5-1,5)$ gibi sekonder metabolitler sayesinde susam yağının oksitlenmeye karşı son derece dirençli olduğu bilinmektedir. (Baydar, 2005; Salunkhe ve ark., 1991). Bu kadar üstün kaliteli özelliklere sahip olmasına rağmen susam bitkisinin düşük tohum verimi, kapsül çatlaması nedeniyle hasat ve harmanının zorluğu, makinalı hasada uygunsuzluğu gibi nedenlerden dolayı tarımı gelişememiştir (Baydar, 2005). Son yıllarda ülkemiz susam ekim alanı yıllara göre dalgalı bir seyir izlemiş ve üretim miktarı artamamıştır (Şekil 6).

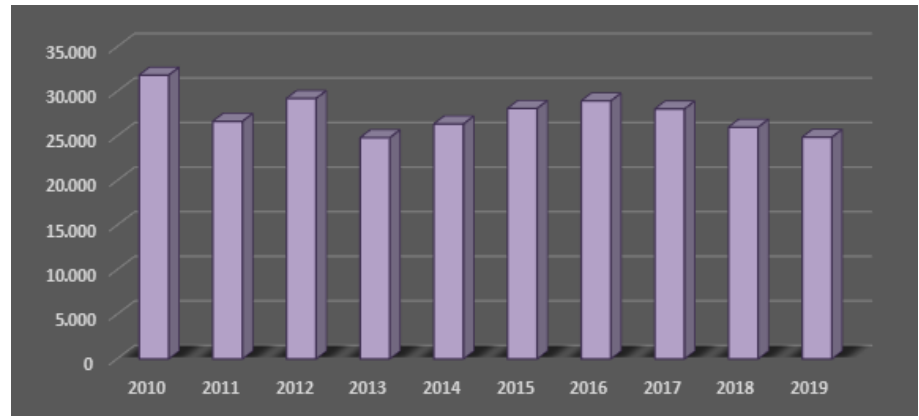

Şekil 6. Türkiye Susam Bitkisi Ekim Alanının Yıllara Göre Dağılımı (ha)

Dünya susam verim ortalaması 51,2 kg/da'dır. TÜİK 2019 verileri incelendiğinde ülkemizde susam bitkisinin ortalama veriminin $68 \mathrm{~kg} / \mathrm{da}$ olduğu görülmektedir. En fazla ekim alanına sahip şehirler sırasıyla Manisa (64 bin da), Antalya (50,8 bin da), Uşak (32,5 bin da), Muğla (28 bin da) ve Adana (15,5 bin da)'dır. Ülkemizde susam tarımının yaygınlaştırılması ve bitkisel yağ olarak üretime katılması için yüksek verim ve kalitede tohum üreten, adaptasyon alanı geniş, makinalı hasada uygun olan çeşitlerin 1slah edilmesi gerekmektedir. 2018/FAO verilerine göre en fazla susam tarımı yapan ülke Sudan $(3,5$ milyon ha)'dır. Ekim alanı olarak bu ülkeyi sırasıyla Hindistan, Myanmar, Tanzanya ve Güney Sudan ülkeleri takip etmektedir (Şekil 7).

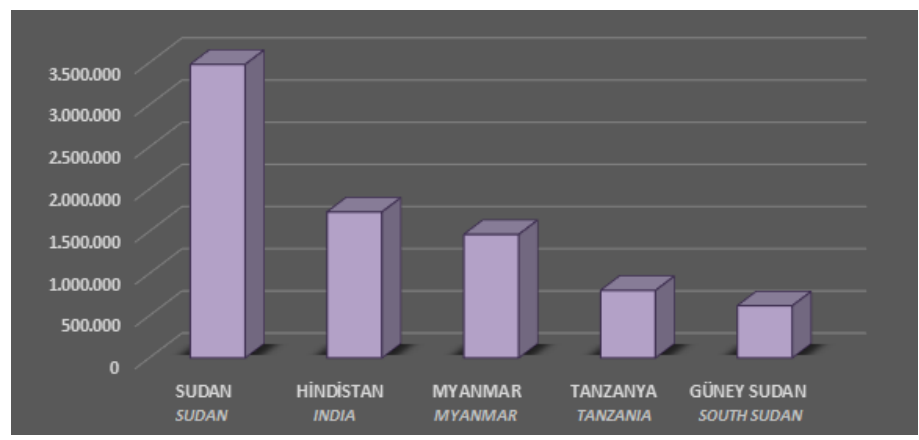

Şekil 5. Dünya'da En Yüksek Susam Ekim Alanına sahip ilk 5 ülke (ha)

Susam bitkisi, yetişme periyodunun kısa olmasından dolayı uygun ekolojik şartlar sağlayan bölgelerde ekim nöbetine sokulabilecek ideal bir yağlı tohum bitkisidir. Ülkemizde yaygın olarak tahıl (buğday, arpa, mısır, çeltik) hasadını takiben ikinci ürün olarak yetiştiriciliği yapılmaktadır (Şahin, 2014). Ülkemizde susam yetiştiriciliğinde gübreleme, bakım gibi 
işlemlerin uygulanmaması, üretimi yapılan bölgeye göre adaptasyonu yüksek olan tescilli çeşitlerin yaygınlaştırılmaması, hasat ve harmanın yoğun insan emeği istemesi, maliyet artırıcı özelliğin olması, düşük makineleşme, çiftçinin ekim nöbeti sistemlerini uygulamaması gibi sorunlar nedeniyle bu bitkiden düşük verim alınmaktadır. Bu sorunlar çözüme kavuşturulur ve devlet desteği sağlanırsa, yağ açığını kapatmada susam bitkisi de alternatif alanlarda kullanılabilecek en önemli bitkiler arasında yer alabilir.

\subsection{Ketencik (Camelina sativa L. Crantz)}

Ketencik, Orta Asya ve Kuzey Avrupa'nın doğal bitkisi olup, arkeolojik kazılardan elde edilen bulgular, bu bitkinin en az 3000 yıldır Avrupa'da yetiştirildiğini ortaya koymuştur. Yakın dönemlerde insan beslenmesinde Omega-3 yağ asitlerinin bitkisel kaynaklardan temin edilmesi fikriyle ketenciğin önemi artmıştır. Ketencik tohumları yaklaşık \%42-45 oranında yăg içermekte ve bu yağ da yüksek oranda (\%35) $\alpha$-linolenik asit (18:3n-3, Omega-3)'ten oluşmaktadır (Umarov ve ark., 1972; Katar ve ark., 2012).

Ketencik, 85-100 günlük vejetasyona sahip olan soğuğa ve kurağa toleransı yüksek, fazla yağış almayan yerlerde yetişebilen, nadas alanlarının daraltılması için kurak bölge topraklarında az miktardaki nem ve besin maddesi isteğinden dolayı kolaylıkla yetiştirilebilecek önemli bir alternatif yă bitkisidir (Vollmann ve ark., 1996). Ketencik yağının 100 gramı, $10 \mathrm{mg}$ E vitamini içermektedir (Zubr, 1997). Zengin antioksidan içeriği sayesinde kozmetik alanında, küspesinin \%10 yağ, \%45 protein içermesinden dolayı kümes hayvancılığında yem bitkisi olarak değerlendirilebilmektedir (Kurt ve Seyis, 2008). Ayrıca süs bitkisi olarak da kullanılmaktadır (Jones ve Valamoti, 2005). Bazı bölgelerde kolzadan daha ucuz üretim maliyeti olduğu için biyodizel üretiminde alternatif bitki olarak kullanıldığı görülmüştür. Amerika'nın Montano eyaletinde yağış az olduğu için 1 yıl buğday ertesi yıl ketencik ekimi yapılmakta ve üretimden elde edilen 800 milyon galon/y1l yağ güvenli bir biyodizel kaynağı olarak kullanılmaktadır (Shonnard ve ark., 2010).

Ketencik, adaptasyonu yüksek, besin maddesi isteği bakımından kanaatkâr, yabancı ot rekabeti iyi ve kuraklığa dayanıklılık özelliği ile alternatif tarım alanlarında tahıllarla yetiştirilebilen iyi bir münavebe bitkisi olarak değerlendirilebilir. Tohumunda bulunan yüksek yağ oranı, dizel ve jet yakıtı gibi kaliteli yakıtlara dönüşecek şekilde işlenebilir (Kurt ve Seyis, 2012). Bu üstün özelliklere rağmen ülkemizde sadece Tarla Bitkileri Merkez Araştırma Enstitüsü tarafından 1 adet (Arslanbey) çeşit geliştirilmiştir. Ülkemizde yă açı̆̆ının giderilmesi için alternatif tarım alanlarının kullanılmasında önemli bir yeri olan ketencik bitkisinin en iyi yetiştirilebileceği bölgeler belirlenmeli, bölgede adaptasyon kabiliyeti yüksek çeşitler geliştirilmelidir.

\subsection{Pelemir (Cephalaria syriaca L.)}

Pelemir, ülkemizde yaygın bir şekilde doğal olarak yetişen, nispeten soğuğa ve kuraklığa dayanıklı, toprak derinliği fazla olmayan eğimli ve erozyona maruz olan marjinal alanlarda bile yetiştirilebilen alternatif bir yağ bitkisidir. Pelemir bitkisinin yağında bulunan \%7-8 dolayındaki epoksi asit bu bitkinin yemeklik olarak kullanılmasını engellemektedir (Sezgin ve ark., e-ISSN: 2148-2683
2017). Diğer taraftan bu bitkinin yağındaki \%19-20 oranında bulunan miristik asit içeriği sabun yapımında ve epoksi asit içeriği deri ve tekstil sanayinde değerlendirilmeye olanak sağlamaktadır (Yazıcıŏglu ve ark., 1978). Ayrıca yağı çıkarıldıktan sonra arta kalan küspesi de hayvan beslemesinde kullanılabilecek önemli bir yem kaynağıdır (Çiller, 1977). Pelemir tohumu yaklaşık \%22-28 yağ ve \%14-21 protein içermektedir (Sezgin ve ark., 2017). Tohumlarından elde edilen un ülkemizde özellikle ekmek yapımı için düşük kaliteye sahip buğdaylardan elde edilen hamuru kuvvetlendirmek, bayatlamasını geciktirmek amacıyla geleneksel olarak kullanılan doğal bir katkı maddesidir (Altıniğne ve Saygın, 1985).

Yaygın olarak tarımı yapılan yağlı tohumlu bitkilere oranla, pelemir tohumları linoleik asit ve miristik asit içeriği yönünden daha yüksek içeriğe sahiptir (Baydar ve Turgut, 1999). Bu sebeple yağı kalite 1 slahı çalışmalarında değerlendirilerek marjinal alanlarda tohum ve yağ verimi açısından istenilen özellikle sahip yeni çeşitler geliştirilebilir. Ayrıca pelemir yağından elde edilen biyodizel yakıt özelliklerinin standartlara uygun olması (Öğüt ve ark., 2014) gelecekte pelemir bitkisinin öneminin artacağını ve alternatif yenilenebilir çevre dostu enerji kaynağı olabileceğini göstermektedir (Altunbaş, 2015). Ülkemizde bugüne kadar sadece 2 adet tescilli pelemir çeşidi geliştirilmiştir. Bu bitkiye olan ilginin daha çok artması ve yeni çeşitlerin geliştirilmesi gerekmektedir.

\subsection{Crambe (Crambe abyssinica Hochst. ex R.E. Fries)}

Crambe bitkisinin tohumları \%37 yağ içermektedir, bu yağın \%57'sini erusik asit oluşturmaktadır. Erusik asit insanlarda sağlık problemleri oluşturduğu için (Parke ve Parke, 1999; West ve ark., 2002) crambe yağı yemeklik yağ olarak kullanıma uygun değildir. Ancak erusik asit (C 22:1) değerinin yüksek olması bu bitkiyi önemli bir endüstri ham maddesi yapmaktadır (Seyis ve ark., 2013). Son yıllarda dünyada crambe yetiştiriciliği artmış A.B.D, İngiltere, Avustralya, Kanada gibi ülkelerde crambe tarımı ve 1slahının kırsal alanlarda yaygınlaştırılması konularında araştırılmalar başlatılmıştır (Bayramin ve Arslan, 2007).

Biyodizel, biyoplastik, boya ve deterjan sanayi gibi çok farklı kullanım alanlarına sahip olan crambe, ülkemizde az yağış alan İç ve Orta Anadolu bölgelerinde su tüketim düşüklüğü sayesinde alternatif yağ bitkisi olarak yetiştirilebilir (Arslan ve ark., 2015). Islah çalışmalarında yüksek erusik asit içeren crambe genotipleri seçilerek endüstri ham maddesi olarak ülkemiz ekonomisine katkı sağlanabilir.

\subsection{Keten (Linum usitatissimum L.)}

Keten bitkisi; bilinen en eski tür olup, lifleri (keten kumaş1, halat, çadır bezi) ve tohumundan elde edilen yağ ile ülkemizde ve dünyada hem gida hem de endüstri ham maddesi olarak kullanılan önemli bir yağ bitkisidir. Keten tohumu bünyesinde yaklaş1k \%30-45 yağ ve \%20-25 protein bulunur (Oomah ve Mazza, 2000). Bu yağın ise \%45-55'i linolenik asit olduğundan çabuk oksitlenip acılaşmaktadır. Linoleik asit oranı \%3’ün üzerindeki genotiplerin yemeklik yağ kalitesi düşüktür ve yemeklik yağ olarak kullanımı sınırlıdır (John, 1992; Salunkhe ve ark., 1992; Yıldırım, 2005). Islah çalışmalarıyla linoleik asit 
oranı \%3'ün altına düşürülen çeşitler yemeklik yağ olarak kullanılmaktadır (Schuster 1992; Sahi ve Leitch 1994). Ülkemizde 2018 yılında ilk keten çeşidini Trakya Tarımsal Araştırma Enstitüsü geliştirmiş ve üretim iznini almıştır. Günümüzde toplam üç adet keten çeşidi üretim izinli olarak ekilmektedir.

Dünyada toplam keten ekimi, 3,3 milyon ha alanda yapılmaktadır. Keten ekim alanı olarak en fazla yetiştiriciliğin yapıldığ 1 ülke Kazakistan (1,08 milyon ha)'dır. Diğer ülkeler ise sirasiyla Rusya (730 bin ha), Kanada (460 bin ha), Hindistan (320 bin ha) ve Çin (280 bin ha)'dir. 2018/Tüik istatistikleri incelendiğinde, ülkemizde keten ekim alanı 2000 yılında 320

\section{Sonuç}

Ülkemizde bitkisel yağ talebi, nüfus artışı ile doğrusal olarak artış göstermektedir. Bitkisel yă̆ açığını gidermek adına yeterli düzeyde üretim gerçekleştirilememektedir. Oransal olarak en yüksek paya sahip ayçiçeği yağı ile toplam bitkisel yağ ihtiyacının sadece bir kısmı karşılanabilmektedir. Yağ bitkileri yetiştiriciliğinin yetersiz olması nedeniyle giderek artan yüksek miktardaki yă̆ açı̆̆ı ise, tohum ve ham yağ ithalatı yoluyla karşılanmaktadır. Bitkisel yağ sanayiinin hammadde ihtiyacının büyük bir bölümü dış ülkelerden sağlanmaktadır. $\mathrm{Bu}$ nedenlerden dolayı ülkemizde ciddi rakamlarda döviz kaybı yaşanmaktadır.

Tahıllar kadar stratejik öneme sahip olan yağlı tohumlu bitkilerin mevcut tarım potansiyellerinin artırılması ile hem ülkemizin gereksinim duyduğu yağ ihtiyacı karşılanmış olacak hem de yă̆ fabrikalarının kapasiteleri artarak yă sektörüne büyük katkılar sağlanmış olacaktır (Arıoğlu ve ark., 2010). Türkiye'de nadas uygulanan yaklaşık 3,4 milyon hektar alan (TÜİK, 2019) alternatif yağ bitkileriyle değerlendirilememekte ve gelişen hayvancılık sektörünün ihtiyacı olan yağlı tohum küspesi yurt dişından ithal edilmektedir. Dünya ve Türkiye yağlı tohum üretim oranları incelendiğinde ülkemiz yağlı tohum ihtiyacının \%53'ünü ayçiçeği tarımından karşılarken dünya \%58'lik bir oranla soya tarımından karşılamaktadır (Şekil 8).

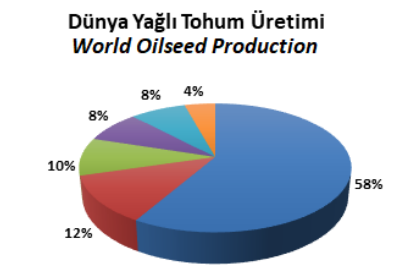

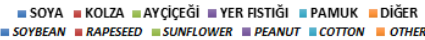

\section{Şekil 8. Dünya ve Türkiye Yağlı Tohum Üretimi Oranları}

Alternatif yağ bitkilerinden kolzanın tarımı yağışın kısmen de olsa yeterli olduğu bölgelerde yapılırken susam, aspir, keten, ketencik gibi alternatif yă̆ bitkilerinin tarımı yağışı yetersiz olduğu kurak bölgelerde (nadas alanlarında) yapılabilmektedir. $\mathrm{Bu}$ bakımdan bu bitkilerin tarımının yaygınlaştırılması yă açığının giderilmesi açısından elverişli ve gereklidir. Alternatif tarım alanlarının bu bitkilerle değerlendirilmesi ülke ekonomisine önemli katkılar sağlayacaktır. hektar iken 2017 yılında 5 hektara kadar gerilemiştir. 2000 y1lında lif keteni üretimi 7 ton, yağ keteni üretimi 173 ton iken, günümüzde hem lif hem de yağ keteni üretimi bulunmamaktadır. Ülkemizde keten üretiminin artırılması; kaliteli ve yüksek verimli keten çeşitlerinin geliştirilmesi, çiftçiye keten tarımı teşvikleri verilerek üretime alınması, yok olma tehlikesiyle karşı karşıya gelen keten tarımının artmasını sağlayacaktır. Yağ açığımızı azaltmak için yenilebilir enerji olarak biyodizel kullanımında da değerlendirilebilen, kışlık olarak da yetiştirilebilen bu bitkinin alternatif yağ bitkileri ürün deseni içerisindeki yerini alması ülkemiz ekonomisi için çok önemlidir (Kurt, 2004).

Alternatif yağ bitkilerinin potansiyelini ortaya koyacak ve üretim miktarını artıracak aşağıda sıralanan uygulamaların hayata geçirilmesi gerekmektedir.

-Nadas alanlarında alternatif yağ bitkisi yetiştiriciliği yapan çiftçilere devlet destekleme primleri ile gübre ve mazot desteklerine ilave farklar verilip bu bitkilerin ekim alanlarının artırılması sağlanmalıdır.

-Alternatif yă̆ bitkilerinde yağ içeriği yüksek sertifikalı tohumluklar geliştirilip bunların çiftçilerin kullanım sahalarına katılması sağlanmalıdır.

-Tarım İl Müdürlükleri’nde ve Tarımsal Araştırma Merkezleri'nde alternatif yă̆ bitkileri ile ilgili Ar-Ge çalışmalarına öncelik verilmelidir.

-Tarım Satış Kooperatifleri ve diğer birlikler alternatif yağ bitkilerinde sertifikalı tohumluk temini ve her türlü teknik destek konularında etkili rol üstlenmeli, sertifikalı tohumlukların alımı da teşvik edilmelidir.

-Alternatif yağ bitkilerinin üretimde yaygınlaştırılması adına tarım ile ilgili tüm teknik elemanların üreticilere hizmet içi eğitim çalışmaları yapmaları ve bu bitkilerin tarımı hakkında geniş çaplı yayım çalışmaları yürütmeleri gerekmektedir.

\section{Kaynakça}

Altıniğne, N., \& Saygın, E. (1985). Pelemir katımlı unlardan yapılan ekmeklerde bayatlama süresi. Glda. 5, 323-332.

Altunbaş, O. (2015). Pelemir bitkisinin pirolizi, Yüksek Lisans Tezi, Selçuk Üniversitesi Fen Bilimleri Enstitüsü, Konya.

Arıŏlu, H.H., Kolsarıcı, Ö., Göksu, A.T., Güllüoğlu, L., Arslan, M., Çalışkan, S., ... \& Arslanoğlu, F. (2010). Yağ bitkileri üretiminin artırılması olanaklar1. Türkiye Ziraat Mühendisleri Birliği VII. Teknik Kongresi, (pp. 361-377), 11-15 Ocak 2010, Ankara.

Arslan B., Eryiğit, T., \& Ekin, Z. (1999). Farklı Hasat zamanlarının aspir (Carthamus tinctorius L.)'in verim ve kalite özelliklerine etkileri. Türkiye 3. Tarla Bitkileri Kongresi. Cilt: II, (pp. 132-133), 15-18 Kasım 1999, Adana.

Arslan, M., Üremiş, İ., Çalışkan, S., \& Çalışkan, M.E. (2007). Bazı Kanola (Brassica napus ssp. oleifera L.) Çeşitlerinin Amik Ovası Koşullarında Yetiştirilebilme Olanaklarının 
Belirlenmesi. Türkiye 7. Tarla Bitkileri Kongresi, Cilt II, (pp. 596-599), 25-27 Haziran 2007, Erzurum.

Arslan, Y., Subaşı, İ., \& Keyvanoğlu, H. (2015). Determination of Some Plants Characteristics of Crambe (Crambe hispanica subsp. abyssinica) Genotypes. Tarla Bitkileri Merkez Araştırma Enstitüsü Dergisi, 24(1), 16-23.

Bahar, E. (1999) “Türkiye'de Bitkisel Yağ Sektörünün Genel Durumu ve Çukurova'daki Bitkisel Yağ işletmelerinin İşletmecilik Sorunları", Doktora Tezi, Çukurova Üniversitesi Fen Bilimleri Enstitüsü, Adana.

Baydar, H. (2005). Susamda (Sesamum indicum L.) verim, yağ, oleik ve linoleik tipi hatların tarımsal ve teknolojik özellikleri. Akdeniz Üniversitesi Ziraat Fakültesi Dergisi, 18(2), 267-272.

Baydar, H. \& Turgut, I. (1999) "Yağlı tohumlu bitkilerde yağ asitleri kompozisyonunun bazı morfolojik ve fizyolojik özelliklere ve ekolojik bölgelere göre değişimi”, Turkish Journal of Agriculture and Forestry 23, 81-86.

Bayramin, S. (2006). Aspir (Carthamus tinctorius L.) / Kolza (Brassica napus spp. oleifera L.) Tarımı ve Islahı. Tarla Bitkileri Merkez Araştırma Enstitüsü Dergisi, 15(1-2), 7485.

Bayramin, S., \& Arslan, Y. (2007) Endüstriyel Yă̆ Bitkisi, Crambe. Biyoyakıt Dünyası Dergisi, 18-22.

Corleto, A., Alba, E., Polignano, G.B., \& Vonghia, G. (1997). Safflower: A multipurpose species with unexploited potential and world adaptability. The research in Italy. IVth International Safflower Conference, (pp. 23-31), 2-7 June 1997, Bari, Italy.

Coşkun, Y. (2014). Aspir (Carthamus tinctorius L)'in kışlık ve yazlık ekim olanakları. Türk Tarım ve Doğa Bilimleri Dergisi, 1(4), 462-468.

Çiller, M. (1977). "Pelemir Tohumu Yağı Üzerine Bir Araştırma".

Dajue, L., \& Mündel, H. (1996). Safflower (Carthamus tinctorius L.) promoting the conservation and use of underutilized and neglected crops. 7. Inst. Plant Genetic Resources Institute (IPGRI), Rome, Italy.

Esendal, E. (1988). Aspir türleri üzerine bir monografi, coğrafi dağılış, türler arası ilişkiler, genetik ve sitogenetik özellikler. Ondokuz Mayıs Üniversitesi Ziraat Fak. Dergisi, 3(1): 139150.

Esendal, E. (2001). Safflower Production and Research in Turkey. 5th Int. Safflower Conf., 23-27 July 2001, Montana, USA.

Gizlenci, M. Acar, M., \& Kayaoğlu, Y. (2007). "Türkiye'de Kolza Gerçeği." 1. Ulusal Yağlı Tohumlu Bitkiler ve Biyodizel Sempozyumu, 28-31 Mayıs 2007, Samsun.

Gizlenci, Ş., Acar, M., \& Şahin, M. (2012). Türkiye'de yenilenebilir enerji kaynaklarının (Biyodizel, biyoetanol ve biyokütle) projeksiyonu. Tarm Makinalart Bilimi Dergisi, 8(3), 337-344.

John, P. (1992). Biosynthesis of the Major Crop Productions. Willey Biotechnology Series. John Wiley and Sons.

Jones, G., \& Valamoti, S.M. (2005). Lallemantia, an imported or introduced oil plant in Bronze Age northern Greece. Veget Hist Archaeobot 14, 571-577. https://doi.org/10.1007/s00334-005-0004-z

Katar, D., Arslan, Y., \& Subaşı, İ. (2012). Ankara Ekolojik Koşullarinda Farklı Ekim Zamanlarının Ketencik (Camelina Sativa (L) Crantz) Bitkisinin Yağ Oranı ve Bileşimi Üzerine Olan Etkisinin Belirlenmesi, Journal of Tekirdag Agricultural Faculty, 9(3).
Kolsarıcı, Ö., Gür, A., Başalma, D., Kaya, M.D., \& İşler, N. (2005). Yağlı Tohumlu Bitkiler Üretimi. TMMOB Ziraat Mühendisleri Odası Türkiye Ziraat Mühendisliği VI. Teknik Kongresi, Cilt I (pp. 409-429), 3-7 Ocak 2005, Ankara.

Kolsarıcı, Ö., Kaya, M.D., Göksoy, A.T., Arıŏlu, H., Kulan, E.G., \& Day, S. (2015). Yağl1 tohum üretiminde yeni arayışlar. TMMOB Ziraat Mühendisleri Odasl, Türkiye Ziraat Mühendisliği VIII Teknik Kongresi, (pp. 413-414). 12-16 Ocak 2015, Ankara.

Kurt, O. (2004). Alternatif Yağ Bitkileri Olarak Keten. Ondokuz Mayıs Üniversitesi, Ziraat Fakültesi Faaliyet Raporu (Basılmamış).

Kurt, O., \& Seyis, F. (2008). An alternative oilseed crop: Camelina (Camelina sativa L. Crantz). Anadolu Journal of Agricultural Sciences (Turkey).

Kurt, O., \& Seyis, F. (2012). Alternatif Yağ Bitkisi: Ketencik [Camelina sativa (L.) Crantz]. Anadolu Tartm Bilimleri Dergisi, 23(2), 116-120.

Liu, J.R., Zheng, Y.Z., \& Xu, R.Q. (1992). Analysis of nutrient quality of seed and screening for prominant germplasms in sesame. Oil Crops of China, 1, (24-26).

Machado, S. (2004). Potential Alternative Crops for Eastern Oregon. Oregon Agricultural Experiment Station Special Report, 1054, (84-102).

Oomah, B.D., \& Mazza, G. (2000). Bioactive Components of Flaxseed: Occurrence. Phytochemicals and phytopharmaceuticals, 106.

Ögüt, H., Oğuz, H., Bacak, S., Aydın, F., Uygun, S., Arslan, Y. \& Subaş1, İ. (2014). "Pelemir biyodizelinin teknik özelliklerinin incelenmesi", Enerji Tarımı ve Biyoyakıtlar 4. Ulusal Çalıştayl, (pp. 45-49), 28-29 Mayıs 2014, Samsun.

Öztürk Ö., Akınerdem, F., Bayraktar, N., \& Ada, R. (2007). Konya koşullarında bazı aspir çeşitlerinin verim, verim unsurları ve yağ oranlarının incelenmesi. I. Ulusal Yağlı Tohumlu Bitkiler ve Biyodizel Sempozyumu, (pp. 191-202), 28-31 Mayis, Samsun.

Parke, D.V. \& Parke, A.L. (1999). Rape seed oil. An autoxidative food lipid. J. of Clinical Bioch. and Nutrition, 26, 51-61.

Raymer, P.L. (2002). Canola: An Emerging Oilseed Crop. In: J. Janick and A. Whipkey (Eds.), Trends in New Crops and New Uses (122-126). Alexandria, VA: ASHS Press.

Sahi, F.H. \& Leitch, M. (1994). Flaxseed products and uses. Journal of the Agricultural Society University of Wales, 33, 545-550.

Salunkhe, D.K., Chavan, J.K., Adsule, R.N., \& Kadam, S.S. (1991). Sesame in world oilseeds: Chemistry, technology and utilization. Van Nostrand and Reinhold, New York.

Salunkhe, D.K., Chavan, S.K., Adjuke, R.N., \& Kadam, S.S. (1992). Nonedible oilseeds. World Oilseeds, Chemistry, Technology and Utilization.

Schuster, W. (1992). Ölflangen in Europa, dlg-verlglas-gmbh, eschborner landstrabe, Germany. 122, 102-107.

Seyis, F., Aydın, E., \& Çopur, M. (2013). "An alternative oilseed crop: crambe (Crambe abyssinica hochst. Ex re Fries)." Anadolu Tartm Bilimleri Dergisi, 28(2), 108-114.

Sezgin, M., Tezcan, H., Şahin, M., Arslan, Y., Subaşı, İ., Demir, İ., \& Koç, H. (2017). Bazı Pelemir (Cephalaria syriaca L.) Çeşitlerinin Türkiye'nin Farklı Ekolojik Koşullarında Verim ve Kalite Değerlerinin Belirlenmesi. Tarim ve Doga Dergisi, 20, 192.

Shonnard, D.R., Williams, L., \& Kalnes, T.N. (2010). Camelinaderived jet fuel and diesel: sustainable advanced biofuels. 
Environmental Progress \& Sustainable Energy, 29(3), 382392.

Şahin, G. (2014). Türkiye'de üretimi azalan önemli bir yă̆ bitkisi susam. Insan ve Toplum Bilimleri Araştırmaları Dergisi, 3(2), 404-433.

Taşkaya, T.B. \& Uçurum, İ.B. (2012). Türkiye'de Bitkisel Yă̆ Açığı, Tarımsal Ekonomi ve Politika Geliştirme Enstitüsü, Tepge Bakış, 14 (2), 1-8.

TÜIKK (2019). Statistical data of TUIK. Retrieved from: https://biruni.tuik.gov.tr/ medas/?kn=104\&locale=tr.

TÜİK (2020). Statistical data of FAO. Retrieved from: https://biruni.tuik.gov.tr/ medas/?kn=92\&locale=tr.

Umarov, A.U., Chernenko, T.V., \& Markman, A.L. (1972). The oils of some plants of the family cruciferae. Khimiya Prirodnykh Soedinenii, 1, 24-27.

USDA (2020). Statistical data of USDA. Retrieved from: https://usda.library. cornell.edu/concern/publications/ tx31qh68h? locale $=$ en.

Uysal, N., Baydar, H., \& Erbaş, S. (2006). Isparta populasyonundan geliştirilen aspir (Carthamus tinctorius L.) hatlarının tarımsal ve teknolojik özelliklerinin belirlenmesi. Ziraat Fakültesi Dergisi, 1(1), 52-63.

Vollmann, J., Damboeck, A., Eckl, A., Schrems, H., \& Ruckenbauer, P. (1996). Improvement of Camelina sativa, an under exploited oil seed. In J. Janick (Ed.), Progress in new crops, 357-362. Alexandria, VA: ASHS Press.
West, L., Balch, B., Meyer, K., \& Huth, P. (2002). Determination and health implication of the erucic acid content of broccoli florets, sprouts and seeds. J. of Food Sci., 67, 2641-2643.

Yazıcıŏ̆lu, T., Karaali, A., \& Gökçen, J. (1978). "Cephalaria syriaca seed oil". Journal of the American Oil Chemists' Society, 55(4), 412-415. DOI: 10.1007/BF02911903

Yıldırım, M. (2005). Seçilmiş alternatif keten (Linum usitatissimum L.) hatlarının verim ve verim öğeleri bakımından karşılaştırılması. Doktora Tezi, Ankara Üniversitesi Fen Bilimleri Enstitüsü, Ankara.

Yoshida, H. \& Takagi, S. (1997). Effects of seed roasting temperature and time on quality characteristics of sesame (Sesamum indicum). Oil. J. Sci. Food Agric., 75, 19-26.

Zhang L.P., Yan, J., \& Chai, Q. (1997). Pharmacological Study of Safflower. IVth International Safflower Conference, (pp. 339-346), 2-7 June, Bari, Italy.

Zubr, J. (1997). Oil-seed crop: Camelina sativa. Industrial Crops and Products, 6, 113-119. 